\title{
LINEAR INTEGRAL INEQUALITIES INVOLVING MAXIMA OF THE UNKNOWN SCALAR FUNCTIONS
}

\author{
Snezhana G. Hristova and Kremena V. Stefanova
}

Abstract. This paper deals with linear integral inequalities that include the maximum of the unknown scalar function of one variable. The considered inequalities are generalizations of the classical integral inequality of Gronwall-Bellman. The importance of these integral inequalities is defined by their wide applications in qualitative investigations of differential equations with "maxima" and it is illustrated by some direct applications.

Mathematics subject classification (2010): 26D10, 34D40.

Keywords and phrases: Integral inequalities, maxima, scalar functions of one variable, differential equations with "maxima".

\section{REFERENCES}

[1] V. G. Angelov, D. D. Bainov, On the functional differential equations with "maximums", Appl. Anal., 16 (1983), 187-194.

[2] D. D. Bainov, P. S. Simeonov, Integral inequalities and applications, Kluwer, 1989.

[3] C. Buse, C. P. Niculescu, J. PeČARIĆ, Asymptotic stability and integral inequalities for solutions of linear systems on Radon-Nikodým spaces, Math. Inequal. Appl., 8 , 2 (2005), 347-356.

[4] Y. Сho, Young-Ho Kim, J. PeČarić, New Gronwall-Ou-Iang type integral inequalities and their applications, ANZIAM J., 50, 1 (2008), 111-127.

[5] K. P. HADELER, Delay equations in biology, New York, Springer, 1979.

[6] S. G. Hristova, L. F. Roberts, Boundedness of the solutions of differential equations with "maxima”, Int. J. Appl. Math., 4, 2 (2000), 231-240.

[7] Q. MA, J. PEČARIĆ, Explicit bounds on some new nonlinear retarded integral inequalities and their applications, Taiwanese J. Math., 13, 1 (2009), 287-306.

[8] Q. MA, J. PEČARIĆ, On certain new nonlinear retarded integral inequalities for functions in two variables and their applications, J. Korean Math. Soc., 45, 1 (2008), 121-136.

[9] Y. H. KIM, On some new integral inequalities for functions in one and two variables, Acta Mathematica Sinica, English Series, 21, 2 (2005), 423-434.

[10] A. D. MishKis, On some problems of the theory of differential equations with deviating argument, Russian Math. Surveys, 32, 2 (1977), 181-210 (in Russian).

[11] B. G. PAChPATtE, Explicit bounds on certain integral inequalities, J. Math. Anal. Appl., 267 (2002), 48-61.

[12] E. P. Popov, Automatic regulation and control, Moscow, 1966 (in Russian).

[13] N. Yoshida, Forced oscillations of solutions of parabolic equations, Bull. Austral. Math. Soc., 36 (1987), 289-294. 